\title{
Jarak Sumber Air Baku Air Minum dari Pusat Erupsi dan Risiko Kesehatan Masyarakat di Wilayah Pasca Erupsi Sinabung
}

\author{
Sri Malem Indirawati ${ }^{1 *}$, Haesti Sembiring ${ }^{2}$ \\ ${ }^{1}$ Departemen Kesehatan Lingkungan FKM Universitas Sumatera Utara, Kota Medan, Sumatera Utara, Indonesia 20222 \\ ${ }^{2}$ Poltekkes Kemenkes RI Medan Jurusan Kesehatan Lingkungan, Medan, Sumatera Utara, Indonesia 20136 \\ *Corresponding author : srimalem@usu.ac.id
}

Info Artikel:Diterima 12 Oktober 2019 ; Disetujui 12 Juni 2020 ; Publikasi 1 Oktober 2020

Cara sitasi (Vancouver): Indirawati S, Sembiring H. Jarak Sumber Air Baku Air Minum dari Pusat Erupsi dan Risiko Kesehatan Masyarakat di Wilayah Pasca Erupsi Sinabung. Jurnal Kesehatan Lingkungan Indonesia [Online]. 2020 Oct;19(2):103-110. https://doi.org/10.14710/jkli.19.2.103-110.

\begin{abstract}
ABSTRAK
Latar belakang: Gunung sinabung sudah mengalami erupsi selama 9 tahun sejak bulan Agustus tahun 2010, hal ini menyebabkan perubahan ekosistem karena telah merubah struktur tanah dan mempengaruhi kualitas air di wilayah erupsi. Kondisi ini menimbulkan faktor risiko kesehatan pada masyarakat yang mengkonsumsi sumber air baku air minum yang tercemar debu vulkanik. Penelitian ini bertujuan untuk menganalis kadar $\mathrm{Pb}$ pada air minum masyarakat dan mengukur risiko kesehatan lingkungan yang timbul sebagai dampak dari erupsi berdasarkan jarak sumber air baku dan mengetahui status kualitas air baku berdasarkan jarak dari pusat erupsi.

Metode: Penelitian survei dengan design cross sectional berlokasi di hunian tetap desa Nang belawan kecamatan Simpang Empat kabupaten Karo propinsi Sumatera utara. Sampel meliputi air baku air minum yang diambil di empat lokasi. Air baku dianalisis dengan alat photometer water test kit AYI-IO, dan kemudian hasilnya dipetakan dengan analisis spasial berdasarkan jarak dari sumber erupsi ke sumber air baku. Sejumlah 56 kepala keluarga diambil secara purposive sampling di wilayah penelitian berdasarkan cemaran $\mathrm{Pb}$ tertinggi, selanjutnya dianalisa dengan metode Analisa Risiko Kesehatan Lingkungan.

Hasil: Seluruh sampel air tercemar Pb dengan rentang $0.17-0.9 \mathrm{mg} / \mathrm{L}$. Masyarakat dengan masa tinggal 4 tahun dan rerata berat badan $55 \mathrm{Kg}$ dan mengkonsumsi $2 \mathrm{~L} /$ hari memiliki risiko kesehatan. Kualitas air baku dengan jarak 9,66 - 11,43 Km dari gunung sinabung belum aman untuk dikonsumsi.

Simpulan: Masyarakat yang bermukim di lokasi hunian tetap Nang Belawan 1 memiliki konsentrasi $\mathrm{Pb}$ maksimum $0,9 \mathrm{mg} / \mathrm{L}$ dan memiliki risiko kesehatan akibat mengkonsumsi air minum yang tercemar $\mathrm{Pb}$. Jarak sumur 11,43 Km dari pusat erupsi tidak aman untuk dikonsumsi. Pengelolaan air baku dengan metode penyaringan khusus dalam upaya menurunkan konsentrasi $\mathrm{Pb}$ perlu dilakukan agar dapat menurunkan risiko kesehatan.
\end{abstract}

Kata kunci: $\mathrm{Pb}$; air minum; pasca erupsi; risiko kesehatan

\section{ABSTRACT}

Title: The Raw Water Source Distance From The Center Of Eruption And Public Health Risks in The Area of Sinabung Post-Eruption

Background: Mount Sinabung has been erupted for 9 years since August 2010, it caused ecosystem changing because it changed the soil structure and will affecting water quality in the eruption area. This condition raises environmental health risks for people who consume drinking water sources contaminated with volcanic dust pollutants. This study aims to analyze the quality of $\mathrm{Pb}$ in community drinking water and environmental health risks that arise as a result of eruptions and knowing the status of raw water quality based on the distance from the eruption center. 
Method: This is survey study with cross-sesctional design was located in Nang Belawan village Simpang Empat sub-District Karo District in North Sumatera Province with four locations for drinking water source samples. The raw water is analyzed by the AYI-IO water test kit, and then the results are mapped with spatial analysis based on the distance from the point of Mount Sinabung. 56 samples were taken by purposive sampling in the area with the highest $\mathrm{Pb}$ contamination, then analyzed by enviromental health risks assesment

Result: All samples of $\mathrm{Pb}$ polluted water ranged from 0.17 to $0.9 \mathrm{mg} / \mathrm{L}$. People with a 4-year stay and average body weight of $55 \mathrm{~kg}$ and consuming $2 \mathrm{~L} /$ day had risks. Raw water with a distance of $9.66-11.43 \mathrm{Km}$ from Sinabung is not safe for consumption.

Conclusion: This indicates that people living in the Nang Belawan 1 Huntap location with maximum Pb concentration of $0.9 \mathrm{mg} / \mathrm{L}$ had a health risk due to contaminated raw water. Need to manage raw water as a source of drinking water with a special screening method, in an effort to reduce the concentration of $P b$. The distance of the well $11.43 \mathrm{Km}$ from the eruption center is not safe for consumption

Keywords: Pb; drinking water; post eruption; health risks assesment; distance

\section{PENDAHULUAN}

Gunung Sinabung merupakan gunung api yang berada di dataran tinggi Karo, Sumatera utara. Gunung ini pernah meletus pada tahun 1600, dan aktif kembali pada bulan Agustus tahun 2010, status dinaikkan menjadi Awas ${ }^{1}$. Gunung ini meletus kembali pada tahun 2013 dengan peningkatan aktivitas berupa letusan-letusan yang semakin menguat, sehingga pada tanggal 3 Nopember 2013 status dinaikkan kembali menjadi siaga. Tepat 24 Nopember 2013 status gunung Sinabung dinaikkan ke level tertinggi yaitu level 4 (awas), akibat rangkaian letusan yang terus terjadi hingga memasuki tahun 2014, status ini terus bertahan. Hal ini menyebabkan jumlah warga mengungsi melebihi 20 ribu orang. Letusan terbesar terjadi pada tanggal 19 Pebruari 2018 dengan ketinggian letusan mencapai $5 \mathrm{Km}^{2}$. Letusan berlanjut pada bulan Mei 2019, letusan yang berkepanjangan selama 9 tahun dapat merubah struktur tanah dan akan mempengaruhi kualitas air di wilayah erupsi gunung sinabung ${ }^{3,4}$.

Kualitas air tanah dapat dipengaruhi oleh kualitas udara khususnya pada daerah letusan gunung berapi seperti yang ditemukan pada air permukaan ditemukan urutan kandungan logam $\mathrm{Zn}>\mathrm{Mn}>\mathrm{Cu}$ $>\mathrm{Co}>\mathrm{Ni}>\mathrm{Pb}>\mathrm{Cr}>\mathrm{As}>\mathrm{Hg}>\mathrm{Cd}^{3}$. Analisis abu vulkanik Sinabung mengandung unsur belerang (S) berkisar antara 0,05- 0,32 \%, besi $(\mathrm{Fe})$ berkisar antara 0,58-3,1 \%, Pb berkisar antara 1,5$5,3 \%$ sedangkan kandungan logam berat seperti $\mathrm{Cd}$, As, Ag dan Ni tidak terdeteksi ataupun sangat rendah sehingga tidak membahayakan ${ }^{5}$. Kadar unsur S ditemukan dalam konsentrasi tinggi pada abu segar ${ }^{6}$, namun pada saat hujan kadar unsur $\mathrm{S}$ akan berkurang. ${ }^{7}$

Berdasarkan hasil analisa selama tahun 20102014 kandungan $\mathrm{Pb}$ belum menunjukkan kondisi di atas baku mutu lingkungan pada lapisan permukaan tanah. Kandungan unsur hara makro yang terlihat cukup tinggi adalah fosfat $\left(\mathrm{P}_{2} \mathrm{O}_{5}\right)$ dan kalium $\left(\mathrm{K}_{2} \mathrm{O}\right)$, dengan retensi fosfat yang tergolong sangat rendah. Kandungan logam berat $\mathrm{Pb}, \mathrm{Cd}$, $\mathrm{As}, \mathrm{Ag}$, dan $\mathrm{Ni}$ tergolong rendah (tidak terdeteksi) sehingga tidak membahayakan tanaman maupun manusia ${ }^{6}$.
Karakteristik debu vulkanik pada Gunung Merapi memiliki kandungan $\mathrm{P}$ dalam abu volkan berkisar 8232 ppm P2O5. kandungan $\mathrm{Mg}$ (0,13-2,40 me/100g), yang tergolong rendah, namun kadar $\mathrm{Ca}$ yang tinggi $(2,13-15,47 \mathrm{me} / 100 \mathrm{~g})$. Sulfur $(2-160 \mathrm{ppm})$, kandungan logam berat Fe (13-57 ppm), Mn (1.5-6,8 ppm), $\mathrm{Pb}(0,1-0,5 \mathrm{ppm})$ dan $\mathrm{Cd}$ cukup rendah $(0,01-$ $0,03$ ppm $)^{8}$.

Penelitian kandungan logam berat dalam tanah pada area erupsi gunung sinabung ditemukan kandungan $\mathrm{Pb}$ pada kedalaman tanah 0-5 cm dan 0$15 \mathrm{~cm}$ masing-masing sebesar $61.01 \mathrm{ppm}$ dan sebesar $70.67 \mathrm{ppm}^{8}$. Perubahan kualitas lingkungan akibat erupsi, khususnya mempengaruhi kualitas sumber air minum masyarakat yang mengandung ion dan logam yang potensial beracun ${ }^{4,9}, 10$. Fakta lain pencemaran udara yang berasal dari air hujan berpengaruh terhadap kualitas air sumur.$^{3,4}$

Hasil survey awal dan pengaduan masyarakat yang bermukim di wilayah hunian tetap (Huntap) yaitu desa Nang belawan I mengeluhkan kualitas air yang meninggalkan bekas kehitaman pada ember penampungan air penduduk. Masyarakat meminta untuk dilakukan pemeriksaan terhadap kualitas air baku air minum mereka. Hasil pemeriksaan terhadap kualitas logam berat ditemukan parameter $\mathrm{Pb}$ telah melebihi baku mutu lingkungan $0,9 \mathrm{mg} / \mathrm{l}$, yang diambil dari sumber air baku air minum masyarakat berdasarkan Permenkes No. 416/MENKES/PER/1990 tentang Persyaratan Kualitas Air Bersih, baku mutu $\mathrm{Pb} 0,05 \mathrm{mg} / \mathrm{L}^{11}$.

$\mathrm{Pb}$ dapat menimbulkan dampak bagi kesehatan melalui kontaminasi dari makanan dan minuman, melalui inhalasi dari udara, dan kontak lewat kulit. Tubuh tidak membutuhkan logam $\mathrm{Pb}$ karena dalam tubuh manusia $\mathrm{Pb}$ dapat menghambat aktivitas enzim yang terlibat dalam pembentukan $\mathrm{Hb}$. Keracunan $\mathrm{Pb}$ bersifat akut dan kronis. Gangguan yang dapat ditimbulkan adalah gangguan gastrointestinal, infertilitas pada laki-laki, aborsi spontan pada wanita, gangguan fungsi syaraf, berupa daya ingat menurun, dan gangguan fungsi ginjal ${ }^{12}$. Penelitian ini menggunakan Studi Health Risk Assesment (analisa risiko kesehatan) yang mengkaji karateristik 
lingkungan yang berpotensi menimbulkan risiko kesehatan sebagai dasar untuk menyusun atau mengembangkan pengelolaan dan pemantauan risiko. Metode ini digunakan untuk mengkaji dampak lingkungan terhadap kesehatan masyarakat yang terdiri dari empat tahap kajian, yaitu identifikasi bahaya, analisis dosis-respon, analisis pemajanan dan karakterisasi risiko ${ }^{12}$. Tujuan dari penelitian ini untuk menganalis kualitas $\mathrm{Pb}$ pada air minum masyarakat dan mengukur besarnya risiko kesehatan lingkungan yang timbul sebagai dampak dari erupsi dan mengetahui status kualitas air baku berdasarkan jarak dari pusat erupsi.

Paparan debu vulkanik dapat terakumulasi pada lapisan tanah, dan dalam jangka waktu yang panjang kandungan $\mathrm{Pb}$ pada debu di tambah dengan $\mathrm{Pb}$ pada lapisan tanah bebatuan bisa menjadi penyebab kadar $\mathrm{Pb}$ pada sumber air baku air minum meningkat. Jika masyarakat memanfaatkan air bersih di lokasi penghunian tersebut secara terus menerus tanpa ada pengolahan maka dikhawatirkan pada jangka waktu yang lama dapat menimbulkan efek pada kesehatan masyarakat. Penelitian sebelumnya telah melakukan analisa kualitas air pada air permukaan seperti sungai namun belum mengukur kualitas air baku air minum masyarakat dan risiko kesehatan yang ditimbulkannya. Hal yang memperkuat dilakukan penelitian ini adalah data dari 4 penyakit terbesar di lokasi penelitian berdasarkan Profil Kesehatan ${ }^{13}$ dengan urutan reumatik, ISPA, hipertensi dan diare dimana beberapa gejala umum keracunan $\mathrm{Pb}$ ditemukan pada data 10 penyakit tersebut. Gejala keracunan $\mathrm{Pb}$ dengan gejala pada orang dewasa adalah hipertensi, nyeri otot dan sendi, mati rasa atau kesemutan di kaki dan tangan, sulit berkonsentrasi atau mengingat sesuatu, sakit kepala, nyeri perut dan lain-lain ${ }^{12,14.15}$.

\section{MATERI DAN METODE}

Jenis penelitian ini adalah survey analitik dengan melakukan penelitian pada sumber air minum masyarakat yang berasal dari sumur bor dan digunakan sebagai sumber air minum utama. Analisa sampel air dengan menggunakan photometer water test kit AYI-IO yang berasal dari empat (4) sumber air dengan lokasi yang berbeda. Populasi adalah semua masyarakat yang bermukim di hunian tetap (HUNTAP) pada desa Nang Belawan I. Selanjutnya sampel diambil dari populasi yang memiliki konsentrasi $\mathrm{Pb}$ tertinggi pada air minum mereka yaitu pada sejumlah 56 KK. Selanjutnya dilakukan pengukuran besarnya risiko kesehatan pada masyarakat yang mengkonsumsi air minum yang terpapar oleh $\mathrm{Pb}$. Pengumpulan data dilakukan pada satu waktu dan dilihat keluhan masyarakat yang muncul sebagai prediksi dari paparan $\mathrm{Pb}$ pada air minum, pengumpulan data ARKL melalui kuesioner. Gambar 1 di bawah ini adalah lokasi pengambilan sampel pada 4 desa di lokasi penelitian yang berjarak 9- $11 \mathrm{Km}$ dari pusat erupsi. Hasil analisa laboratorium untuk data konsentrasi $\mathrm{Pb}$ pada sumber air minum dengan data ukuran jarak dari pusat erupsi di analisa secara spasial, dimana titik sampel air di kumpulkan dengan alat GPS merk Garmin.

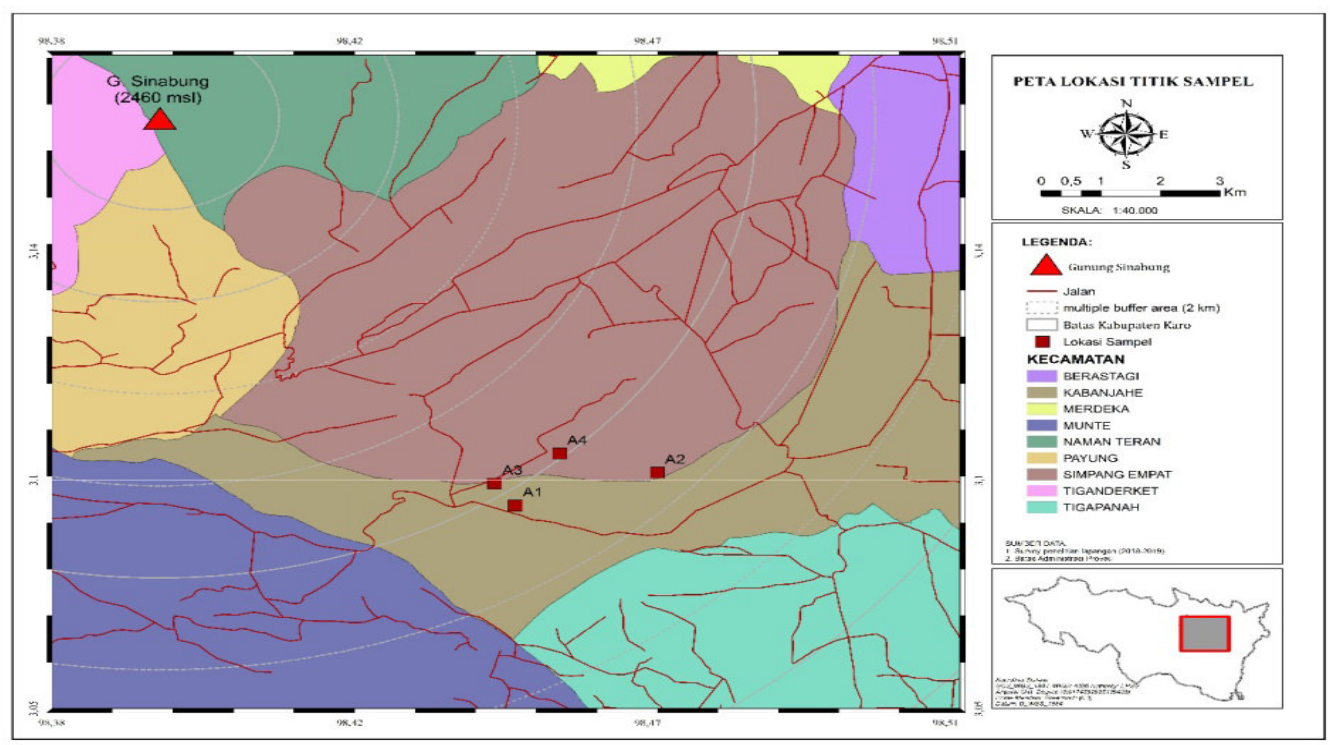

Sumber : Peta hasil analisa data titik sampel

Gambar 1. Lokasi Titik Sampel Penelitian 


\section{Analisis Data Risiko Kesehatan Lingkungan}

(ARKL)

Analisis data untuk mengukur besarnya paparan $\mathrm{Pb}$ pada air minum menggunakan metode analisis risiko kesehatan lingkungan (ARKL). Metode ini memiliki empat tahapan yaitu: ${ }^{12}$

Pertama, identifikasi hazard (identifikasi bahaya) yaitu melakukan pengukuran konsentrasi $\mathrm{Pb}$ pada sumber air minum penduduk.

Kedua menganalisis jalur pemajanan agen risiko dengan tujuan untuk mengukur jumlah asupan air minum. Data yang dikumpulkan adalah konsumsi air minum (1/hari), Konsentrasi risk agent (mg/L), waktu pajanan (jam/hari), frekuensi pajanan (hari/tahun), dan durasi pajanan (tahun).

Rumus Intake ( I)

$$
I=\frac{G \times \mathrm{R} \times \int_{\mathbb{E}} \times D_{i}}{W_{\mathrm{b}} \times t_{\mathrm{nan}}}
$$

Keterangan :

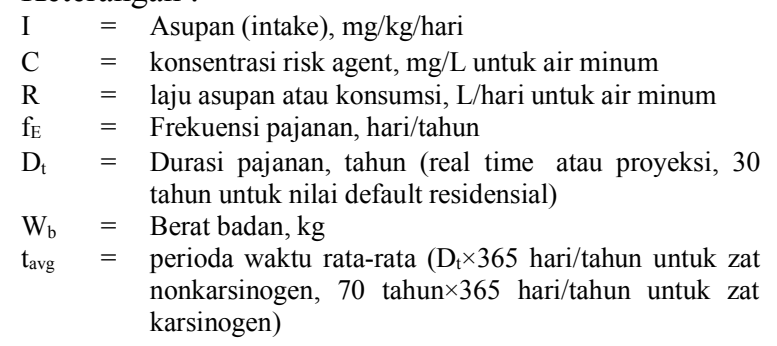

Ketiga, analisis dosis respon yaitu menetapkan nilai toksisitas $\mathrm{Pb}$ sebagai risk agent dinyatakan dengan $R_{f} D$ (melalui intake minuman) Nilai ini sudah tertera dalam Integrated Risk Information System dari US $\mathrm{EPA}^{16}$, RfD $\mathrm{Pb}=3.5 \times 10^{-3} \mathrm{~S}$.

Ke empat, perkiraan risiko (Karakterisasi risiko) yaitu menghitung rasio antara asupan (intake) dengan dosis acuan $(R f D)$ dengan rumus sbb:
Risk Quatient $(R Q)=\underline{\text { Intake }(\mathrm{mg} / \mathrm{kg} \text { hari) }}$ (2) $R f D$

Risiko disebut ada jika nilai $\mathrm{RQ}>=1$ dan Jika $\mathrm{RQ}<1$ risiko belum muncul namun segala kondisi dipertahankan agar nilai RQ tidak melebihi $1^{15}$.

\section{Analisis Data Spasial}

Data spasial adalah data yang memiliki informasi lokasi, sebaran spasial di wilayah penelitian dipetakan berdasarkan hasil analisis konsentrasi $\mathrm{Pb}$ berdasarkan lokasi sampel yang diplotkan dalam peta dasar dengan menggunakan koordinat pengambilan sampel di lapangan. Selanjutnya penentuan tingkat konsentrasi parameter logam berat diinterpolasikan dengan menggunakan metode Inverse distance weighted (IDW) ${ }^{17,18}$. Metode interpolasi ini dengan system geostatistik. Asumsi dari metode ini adalah nilai interpolasi akan lebih mirip pada data sampel yang dekat daripada yang lebih jauh. Bobot (weight) akan berubah secara linier sesuai dengan jaraknya dengan data sampel. Titik-titik yang lebih dekat ke lokasi akan diberi bobot lebih besar. Hasil interpolasi data parameter konsentrasi $\mathrm{Pb}$ pada sumur bor masyarakat disajikan dalam bentuk peta sebaran pencemaran logam $\mathrm{Pb}$ berdasarkan jarak dari lokasi gunung sinabung yang diasumsikan sebagai sumber pencemar.

\section{HASIL DAN PEMBAHASAN}

Hasil analisis konsentrasi $\mathrm{Pb}$ dalam air baku pada tabel 1 di bawah ini, diperoleh hasil dari ke empat lokasi sampel berada pada rentang 0,17 - 0,9 $\mathrm{mg} / \mathrm{L}$, nilai ini berada jauh di atas kadar maksimum yang diperbolehkan yaitu $0.05 \mathrm{mg} / \mathrm{L}$ (Permenkes No 416 Tahun 1990 Tentang Syarat-syarat dan Kualitas air) ${ }^{11}$.

Tabel 1. Data Lokasi Sampel Dan Konsentrasi Pb

\begin{tabular}{lcclrrrrr}
\hline Kode & Lat & Lon & Lokasi & $\begin{array}{l}\text { Jarak } \\
\text { Sinabung } \\
(\text { Km) }\end{array}$ & $\begin{array}{r}\text { Jumlah } \\
\text { KK }\end{array}$ & $\begin{array}{l}\text { Kedalaman } \\
\text { Sumur }(\mathrm{m})\end{array}$ & $\mathrm{PH}$ & $\mathrm{Pb}(\mathrm{mg} / \mathrm{L})$ \\
\hline 1.A1 & 3.09381 & 98.44559 & Nang belawan I & 10.32 & 56 & 84 & 7.6 & 0.9 \\
2.A2 & 3.10027 & 98.46705 & $\begin{array}{l}\text { Mesjid Nang } \\
\text { Belawan }\end{array}$ & 11.43 & - & 60 & 6.75 & 0.24 \\
3.A3 & 3.09814 & 98.44250 & Nang Belawan 2 & 9.66 & 341 & 80 & 7.03 & 0.37 \\
4. A4 & 3.10404 & 98.45231 & $\begin{array}{l}\text { Desa Nang } \\
\text { Belawan }\end{array}$ & 9.86 & 310 & 80 & 6.74 & 0.17 \\
\hline
\end{tabular}

Sumber : data diolah

Tabel 1. di atas ini mendeskripsikan jarak titik sampel dengan lokasi gunung Sinabung, dimana dalam penelitian ini diasumsikan sebagai sumber pencemar $\mathrm{Pb}$ adalah debu vulkanik. Semua kualitas air dengan parameter $\mathrm{Pb}$ berada di atas kadar maksimum yang diperbolehkan. Konsentrasi $\mathrm{Pb}$ tertinggi justru berada pada jarak $10.32 \mathrm{Km}$ yaitu
Huntap Nang Belawan I, dimana desa ini dihuni oleh masyarakat pengungsi yang sudah menetap selama 4 tahun, jumlah keluarga yang bermukim sejumlah 56 KK. Berdasarkan hasil survey masyarakat mengeluhkan air yang jernih namun meninggalkan endapan hitam dan melekat pada ember tempat 
penyimpanan air sementara. Lokasi sampel berada di wilayah kecamatan simpang Empat Kabanjahe.

Hasil analisis spasial pada Gambar 2 berikut ini adalah hasil analisis spasial konsentrasi terhadap jarak titik sampel dari gunung Sinabung sebagai pusat zat pencemar. Gambar ini menjelaskan konsentrasi terlihat semakin tinggi dengan semakin cerahnya warna, pada peta. Lokasi berada pada desa Nang Belawan yang berjarak $10.32 \mathrm{Km}$ dari pusat erupsi gunung sinabung.

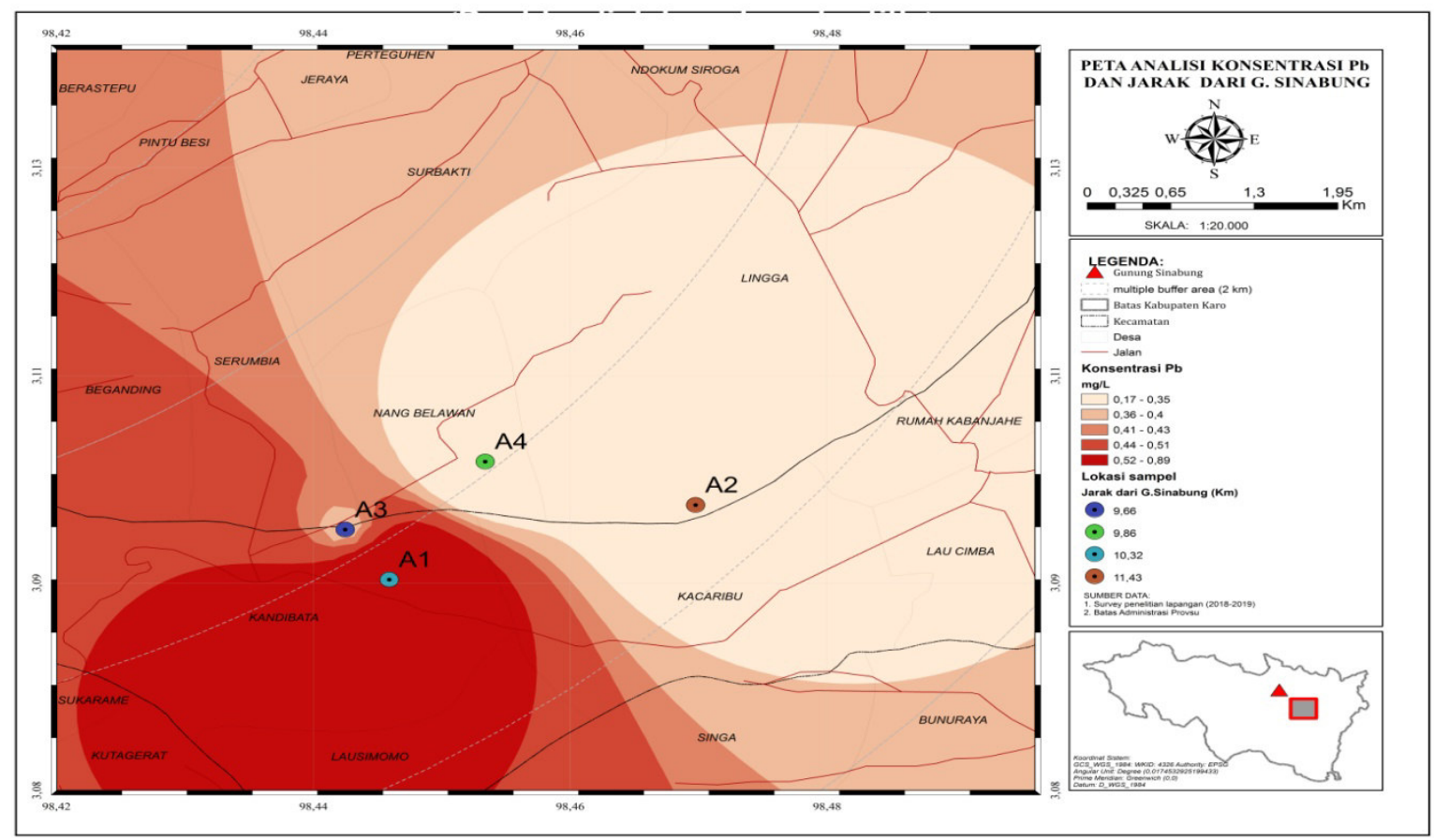

Gambar 2. Peta spasial konsentrasi $\mathrm{Pb}$ dan jarak sumber air baku air minum dari pusat gunung Sinabung

Hasil pemeriksaan sampel diperoleh konsentrasi $\mathrm{Pb}$ tertinggi ada pada lokasi Huntap Nang Belawan I yaitu $0.9 \mathrm{mg} / \mathrm{l}$ sedangkan terendah pada desa Nang Belawan $0.17 \mathrm{mg} / \mathrm{l}$. Berikut adalah hasil perhitungan untuk nilai maksimal konsentrasi $\mathrm{Pb}$ dengan lama tinggal di Huntap selama 4 tahun, jika responden mengkonsumsi air minum $2 \mathrm{~L} /$ hari dengan rerata berat badan $55 \mathrm{Kg}$ dapat dihitung Intake dalam durasi pajanan sebagai berikut:

\section{A. Konsentrasi $\mathrm{Pb}$ dengan nilai maksimum (0.9} $\mathrm{mg} / \mathrm{l})$

$\mathrm{I}_{\mathrm{nk}(4 \text { tahun })}=\underline{0,9 \mathrm{mg} / \mathrm{L} \times 2 \mathrm{~L} / \text { hari } \times 350 \text { hari } / \text { tahun } \times 4}$ $\underline{\text { tahun }}=2520 / 602250$

tahun

$55 \mathrm{~kg}$ x 365 hari/tahun x 30

$$
=0.0042 \mathrm{mg} / \mathrm{kg} / \mathrm{hari}
$$

$\mathrm{RQ}_{(4 \text { tahun })}=\frac{0.0042}{0.0035} \mathrm{mg} / \mathrm{kg} / \mathrm{hari}=1.19$

Nilai RQ untuk masa tinggal 4 tahun sudah menunjukan risiko ( $\mathrm{RQ}>1)$, Jika dibandingkan dengan hasil estimasi risiko pada Tabel 2 di bawah ini:

Tabel 2. Faktor pemajanan antropometri populasi berisiko masyarakat Huntap Nang Belawan

\begin{tabular}{ll}
\hline Faktor Pemajanan & Nilai Numerik \\
\hline Berat Badan rata-rata $\left(W_{b}\right)$ & $55 \mathrm{Kg}$ \\
Lama Pajanan $\left(t_{E}\right)$ & $24 \mathrm{jam} / \mathrm{hari}$ \\
Frekuensi Pajanan $\left(f_{E}\right)$ & 350 hari per tahun \\
Durasi Pajanan $\left(D_{\mathrm{t}}\right)$ & 30 Tahun (life time) \\
Laju asupan & $2 \mathrm{~L} / \mathrm{jam}$ \\
$R f D P b$ & $3.5 \times 10^{-3}$ \\
Source: USEPA IRIS $(2011)^{19}$. & \\
\hline
\end{tabular}

Risiko selama 10 tahun dan 30 tahun yang akan datang, dapat di hitung dengan tahapan berikut :

a. Prediksi Risiko setelah bermukim 10 tahun Ink $(10$ tahun $)=\underline{0,9 \mathrm{mg} / \mathrm{L} \times 2 \mathrm{~L} / \text { hari } \times 350 \text { hari/tahun } \times 10}$ $55 \mathrm{~kg} \times 365$ hari/tahun x 30 tahun $=0.010 \mathrm{mg} / \mathrm{kg} / \mathrm{hari}$

$\mathrm{RQ}_{(10 \text { tahun })}=\underline{0.010} \mathrm{mg} / \mathrm{kg} /$ hari $=2.98$ $0.0035 \mathrm{mg} / \mathrm{kg} /$ hari

b. Prediksi Risiko setelah bermukim 20 tahun $\mathrm{I}_{\mathrm{nk}(20 \text { tahun })}=\underline{0,9 \mathrm{mg} / \mathrm{L} \mathrm{x} 2 \mathrm{~L} / \text { hari } \times 350 \text { hari } / \text { tahun } \times 20}$ $55 \mathrm{~kg} \times 365$ hari/tahun $\times 30$ tahun $=0.020 \mathrm{mg} / \mathrm{kg} / \mathrm{hari}$ 
$R Q(20$ tahun $)=\frac{0.020}{0.0035} \quad \begin{aligned} & \mathrm{mg} / \mathrm{kg} / \mathrm{hari}=5,71 \\ & \mathrm{mg} / \mathrm{kg} / \text { hari }\end{aligned}$

Berdasarkan perbandingan tiga durasi pajanan terbukti bahwa besaran risiko (RQ) responden yang memiliki berat badan $55 \mathrm{~kg}$ dengan mengkonsumsi 2 $\mathrm{L} /$ hari akan berisiko $(\mathrm{RQ}>1)$ jika terpapar selama 4 , 10 tahun dan 20 tahun di lingkungan pemukiman tanpa adanya pengelolaan. Hasil penelitian ini sesuai dengan penelitian yang dilakukan di Makasar yang meneliti besarnya risiko akibat konsumsi air minum, makanan laut yang telah tercemar $\mathrm{Pb}$ dengan nilai $\mathrm{RQ}$ $>1^{20}$, namun berbeda dengan hasil penelitian yang dilakukan oleh Indirawati SM dengan mengambil sampel air minum yang telah tercemar $\mathrm{Pb}$ pada masyarakat di pesisir pantai Belawan di kota Medan ditemukan nilai RQ $<1^{21}$ walaupun sumber air minum sudah tercemar $\mathrm{Pb}$ namun belum beresiko.

\section{B. Konsentrasi $\mathrm{Pb}$ dengan nilai minimum $(0.17$ $\mathrm{mg} / \mathrm{l})$}

a. Prediksi Risiko setelah bermukim 4 tahun $\mathrm{I}_{\text {nk }}$ (4 tahun) $0,17 \mathrm{mg} / \mathrm{L} \times 2 \mathrm{~L} /$ hari $\times 350$ hari/tahun $\times 4$ $55 \mathrm{~kg} \times 365$ hari/tahun $\times 30$ tahun $=0.0007 \mathrm{mg} / \mathrm{kg} / \mathrm{hari}$

$R Q(4$ tahun $)=\frac{0.0007}{0.0035} \quad \begin{aligned} & \mathrm{mg} / \mathrm{kg} / \mathrm{hari} \\ & \mathrm{mg} / \mathrm{kg} / \mathrm{hari}\end{aligned}$

Berdasarkan perhitungan besarnya risiko untuk konsentrasi minimum terbukti belum menimbulkan risiko setelah menetap selama 4 tahun dimana $\mathrm{RQ}<1$.

Survey epidemiologi bisa menemukan gejala atau penyakit berbasis toksisitas $\mathrm{Pb}$ dapat dihitung durasi pajanan berapa lama risiko mulai harus dikendalikan dengan menyusun ulang persamaan (1) dan $\mathrm{I}_{\mathrm{nk}}$ disubstitusi dengan RfD menjadi persamaan (3) yang telah diuraikan di atas.

$$
\begin{gathered}
\mathrm{Rfd}=\mathrm{I}_{\mathrm{nk}} \\
\mathrm{Dt}=\frac{R f D \times \mathrm{W}_{\mathrm{b}} \times \mathrm{t}_{\mathrm{avg}} \text { (tahun) }}{\mathrm{C} \times \mathrm{R} \times \mathrm{f}_{\mathrm{E}}} \\
=\frac{0.0035 \times 55 \times 365 \text { hari/tahun } \times 30 \text { tahun }}{0.9 \mathrm{mg} / \mathrm{L} \times 2 \mathrm{~L} / \text { hari } \times 350 \text { hari } / \text { tahun }} \\
=0,38 \text { tahun }=4.5 \text { bulan }
\end{gathered}
$$

Ini berarti, efek toksik $\mathrm{Pb}$ diestimasi akan ditemukan pada orang dewasa dengan berat badan 55 $\mathrm{kg}$ yang telah mengkonsumsi air minum mengandung $\mathrm{Pb} 0.9 \mathrm{mg} / \mathrm{L}$ (konsentrasi maksimum saat penelitian) selama 4.5 bulan dengan laju konsumsi $2 \mathrm{~L} /$ hari.

Konsentrasi minimum $0.17 \mathrm{mg} / \mathrm{l}$ akan menimbulkan risiko setelah tinggal selama 17 tahun 7 bulan seperti dalam perhitungan di bawah ini

$$
\begin{aligned}
\text { Dt } & =\frac{R f D \times \mathrm{W}_{\mathrm{b}} \times \mathrm{t}_{\mathrm{avg}} \text { (tahun) }}{\mathrm{C} \times \mathrm{R} \mathrm{f}_{\mathrm{E}}} \\
& =\frac{0.0035 \times 55 \times 365 \text { hari } / \text { tahun } \times 30 \text { tahun }}{0.17 \mathrm{mg} / \mathrm{L} \times 2 \mathrm{~L} / \text { hari } \times 350 \text { hari } / \text { tahun }}
\end{aligned}
$$

$$
=17,7 \text { tahun }
$$

Masyarakat dengan berat $55 \mathrm{~kg}$ mengkonsumsi air 2L/hari dengan konsentrasi $\mathrm{Pb} 0.17 \mathrm{mg} / \mathrm{l}$ akan mendapatkan efek dari pencemaran $\mathrm{Pb}$ pada air minum setelah 17,7 tahun kemudian, sedangkan masyarakat dengan karakteristik yang sama dan mengkonsumsi $\mathrm{Pb}$ dengan konsentrasi maksimum 0,9 $\mathrm{mg} / \mathrm{L}$ sudah mengalami risiko setelah menetap selama 4.5 bulan.

\section{Keluhan Penyakit}

Data keluhan penyakit responden dalam 3 bulan terakhir menunjukkan beberapa ciri-ciri keluhan keracunan logam berat $\mathrm{Pb}$. Keluhan kesehatan yang diderita oleh responden pada dasarnya merupakan gejala umum seperti mual, sakit kepala, sakit pinggang, kepala pusing, terasa lemas, diare, hipertens $\mathrm{i}^{22}$ merupakan keluhan kesehatan yang pernah dialami oleh sampel penelitian dalam tiga bulan terakhir. Keluhan - keluhan tersebut belum dapat dipastikan sebagai gejala keracunan akibat logam berat karena masih banyak faktor pendukung lain yang dimungkinkan turut memicu munculnya keluhan tersebut seperti pengaruh pola makan yang menyebabkan keluhan lambung (maag) sehingga responden merasa mual, nafsu makan kurang, terasa lemas, dan berat badan menurun. Hal tersebut di atas dapat dibuktikan jika dilakukan pengambilan sampel darah, urine, atau rambut sebagai biomonitoring logam pada tubuh manusia ${ }^{23}$.

Berdasarkan hal tersebut perlu dilakukan pemeriksaan lanjut dengan biomarker pada masyarakat yang terpapar di desa Nang belawan 1 .

Manajemen risiko yang dapat dilakukan adalah dengan mengupayakan asupan (I) lebih kecil atau sama dengan dosis referensi (RfD). Berikut penjelasan cara-cara manajemen risiko

1. Hal yang dapat dilakukan adalah mengupayakan agar nilai Intake sama dengan RfD.

2. Menurunkan konsentrasi $\mathrm{Pb}$ pada air minum, dengan melakukan pengelolaan terhadap air bersih serta mengurangi jumlah konsumsi air minum Hal ini bisa dilakukan dengan penyaringan air melalui filter tertentu yang dapat menyerap logam $\mathrm{Pb}$.

3. Mengurangi waktu kontak, apabila konsentrasi risk agent dan pola konsumsi tidak dapat diubah.

\section{SIMPULAN}

Hasil penelitian menemukan kosentrasi $\mathrm{Pb}$ pada sumber air baku air minum pada ke empat lokasi berada di atas batas yang diperkenankan (Permenkes No. 416/MENKES/PER/1990 tentang Persyaratan Kualitas Air Bersih) . Konsentrasi $\mathrm{Pb}$ berada pada kisaran $0.17-0,9 \mathrm{mg} / \mathrm{l}$ dan konsentrasi tertinggi berada pada jarak $10.32 \mathrm{Km}$ dari gunung Sinabung. 
Hasil analisis risiko kesehatan (RQ) faktor penyebab penyakit lebih besar dari satu (1) $(\mathrm{RQ}>1)$ berarti bahwa Pencemaran $\mathrm{Pb}$ pada sumber air baku air minum menyebabkan risiko kesehatan pada masyarakat yang bermukim di hunian tetap (HUNTAP) Nang Belawan 1. Hal ini membuktikan bahwa erupsi berdampak terhadap kualitas air baku air minum masyarakat ${ }^{24,25,26 \text {. }}$

\section{DAFTAR PUSTAKA}

1. Togatorop P M, Subiyanto S, Wijaya, AP. Pemetaan potensi bencana aliran lava gunung sinabung menggunakan Citra Aster GDEM; Jurnal Geodesi Undip 2016, 5(2):87-96

2. Simatupang L. dan Devi, The preparation and characterization of Sinabung volcanic ash as silica based adsorbent. Jurnal Pendidikan Kimia 2016 , (8(3):159-163

Doi: 10.24114/jpkim.v8i3.4478

3. Zhaoyong Z. Abuduwaili J. Fengqing. Heavy metal contamination, sources, and pollution assessment of surface water in the Tianshan Mountains of China. Enviromental and Assesment Journal 2015, (187) : 33-39. doi: 10.1007/s10661-014-4191-x.

4. Charles M. Balagizi, Marcellin M. Kasereka , Emilio Cuoco, and Marcello Liotta. Environmental and health impacts of Nyiragongo and Nyamulagira Volcanoes, East Africa. Geophysical Research Proceeding 2019, Vol. 21, EGU2019-5695.

5. Badan Penelitian dan Pengembangan Pertanian (Balitbangtan). Hasil Kajian dan Identifikasi Dampak Erupsi Gunung Sinabung Pada Sektor Pertanian. Jakarta; 2015.

6. Stewart C a, $\square$, Johnston D. M , Leonard G. S, Horwell C. Thordarson, Cronin s.J. Contamination of water supplies by volcanic ashfall: A literature review and simple impact modelling, Journal of Volcanology and Geothermal Research 2006 ( 158 ): 296-306. doi: 10.1016/j.jvolgeores.2006.07.002

7. Beatrix I L. Sinaga J. Sembiring M. Lubis. The Impact of Volcanic Ash Thickness from Sinabung Mount Eruption about the Biological Characteristic of the Soil in the Naman Teran Sub District, Karo District. Jurnal Online Agroekoteknologi 2015, 3(3): 1159-1163.

8. Sukarman dan Suparto, Sebaran dan Karateristik Material Vulkanik Hasil Erupsi Gunung Sinabung di Sumatera Utara, Jurnal Tanah dan Iklim 2015, 39 (1): 9-18

9. Barasa RF. Rauf A. Sembiring M. Dampak Debu Vulkanik Letusan Gunung Sinabung terhadap Kadar $\mathrm{Cu}, \mathrm{Pb}$, dan $\mathrm{B}$ tanah di kabupaten karo 2013. Jurnal Online Agroekoteknologi 1(4)013 (1) :1288-1298

10. Wahyuni E T. Triyono S. dan Suherma. Penentuan Komposisi Kimia Abu Vulkanik Dari
Erupsi Gunung Merapi. Jurnal Manusia Dan Lingkungan 2015, 19 (2) 150-159

11. Peraturan Kemenkes RI. No 416 tentang Syaratsyarat dan Kualitas air, Jakarta 1990.

12. EnHealth. Enviromental Health Risks Assesment, Guidelines for Assesing Human Health Risks From Enviromental Hazards. Department of Health and Ageing and enHealth. Australia Council ;2002.

13. Profil Kesehatan Puskesmas Kecamatan Simpang Empat. Kabanjahe ; 2017.

14. Onyinyechi G. Onyele and Emeka D. Anyanwu. Human health risk assessment of some heavy metals in a rural spring, southeastern Nigeria. African Journal of Environment and Natural Science Research 2018, 1 (1):15-23

15. Cuoco E. Tedesco D. Robert J. Poreda. Jeremy C.Williams. Francesco C, Balagizi C. Thomas H. Darrah. Impact of volcanic plume emissions on rain water chemistry during the January 2010 Nyamuragira eruptive event: Implications for essential potable water resources. Journal of Hazardous Materials 2010, ( 244) : 570-581.

16. World Health Organization and International Programme on Chemical Safety International Programme on Chemical Safety (IPCS). Environmental Health Criteria XXX: Principles for modelling dose-response for the risk assessment of chemicals (Draft). Geneva; 2004

17. Sayful H. Metode Interpolasi Spasial dalam Studi Geografi. Jurnal Geomedia. 2013,.11(2): 235-236.

18. Indarto, F. Konsep Dasar Analisis Spasial. Yogyakarta C.V Andi Offset, 2012: 6-9.

19. US EPA. Integreted risk information system (IRIS).US EPA,office of Research and Development, National Center for Enviromental Assessment, 2006.

20. Birawida AB. Model Dinamis Dan Analisa Risiko Sebaran Logam Berat Timbal Terhadap Kesehatan Masyarakat Pesisir Makassar. Disertasi Perpustakaan FK UNHAS Makasar.2014

21. Indirawati SM. Enviromental Health Risks on Community in Coastal Area As a Results The Presence of $\mathrm{Pb}$ in Sea Water and Drinking Water. IOP Conf. Series: Materials Science and Engineering 2017, (300): 1-8.

22. Esquinas. Garcia. Lead, Mercury and Cadmium in Umbilical cord blood and its association with parental epidemiological variables and birth factor. BMC Public Health Journal 2013, (13) :84-90. doi: 10.1186/1471-2458-13-841

23. Hafiza N. AR. Drinking water studies: A review on heavy metal, application of biomarker and health risk assessment (a special focus in Malaysia). Journal of Epidemiology and Global Health 2015, 1(1): 297-310. Doi: 10.1016/j.jegh.2015.04.003 
24. Bamuwamye M, Ogwok P, Tumuhairwe V, Eragu R, Nakisozi H \& Patrick E. Ogwang. Human Health Risk Assessmentof Heavy Metalsin Kampala (Uganda) Drinking Water. Journal of Food Research 2017, 6 (4):6-16. doi: 10.5539/jfr.v6n4p6

25. Emilio Cuoco, Dario Tedesco, Robert J. Poreda, Jeremy C. Williams, Stefano De Francesco, ,Charles Balagizi, Thomas H. Darrah,
Impact of volcanic plume emissions on rain water chemistry during the January 2010 Nyamuragira eruptive event: Implications for essential potable water resources . Journal of Hazardous Materials 2013, (244-245): 570-581

26. Shin Jang C. 2011. Regional assessment of groundwater quality for drinking purpose, Environ Monit Assess 2011, (184) p:3063-3075 